\title{
Aspekty současné neuroonkologie
}

\author{
doc. MUDr. Radim Jančálek, Ph.D. - editor hlavního tématu \\ Neurochirurgická klinika FN u sv. Anny v Brně a Lékařské fakulty Masarykovy univerzity, Brno
}

Epidemiologické studie posledních let dokladují prodlužující se dobu života a s tím souvisejíci stárnutí lidské populace. Svou pozitivní roli zde nepochybně hraje vysoká úroveň současné medicíny. Tento epidemiologický trend ovšem přispívá k nárůstu počtu onkologických pacientů a tedy i pacientů s nádory nervového systému. Celkově Ize tedy ríci, že i když tvoří primární nádory nervového systému pouze 1-2\% všech novotvarů s incidencí 7,6 prípadů na 100000 obyvatel (Národní onkologický registr ČR), představují skupinu závažných onemocnění s vysokou morbiditou a mortalitou. Narůstající incidence primárních nádorů mozku a míchy (20\% nárůst incidence mezi lety 2000 a 2010 dle Národního onkologického registru ČR) a pokroky v léčbě onkologické budou i nadále zvyšovat prevalenci těchto pacientů (40\% nárůst prevalence mezi lety 2000 a 2010 dle Národního onkologického registru ČR). Prodlužování celkového přežití pacientů s malignitami navíc poskytuje primárně extrakraniálním nádorům delší čas na vytvoření sekundárního metastatického postižení, což vede ke zvyšování počtu pacientů s diagnostikovanými mozkovými metastázami. Léčba pacientů s nádory nervového systému se tak dostává do popředí zájmu mnoha výzkumných i klinicky orientovaných týmů, což odráží nárůst významu mezinárodních odborných společností jako je European Association of Neuro-Oncology nebo americká Society for Neuro-Oncology. Také Česká republika respektuje ustanovením Neuroonkologické sekce při České onkologické společnosti ČLS JEP (www.neurooncology.cz) tento celosvětový trend interinstitucionálního charakteru spolupráce.
Účinný boj se zákeřným onkologickým onemocněním nervového systému vyžaduje multioborovou péči, na které se podílí nejen neurochirurg a onkolog, ale i radiolog, histopatolog, molekulární biolog a v neposlední řadě i neurolog. Právě neurolog pak hraje klíčovou roli v časném rozpoznání možného onkologického onemocnění nervového systému a odeslání pacienta do specializovaného centra. Vzhledem k významné roli neurochirurga $\checkmark$ iniciálních fázích diagnostiky a léčby nádorů nervového systému je tento nejčastěji konfrontován s CT nebo MR nálezem expanzivního procesu s cílem zajistit co největší resekci nádoru a získat histologický materiál pro jeho typizaci a grading. V poslední době narůstá význam tkáňových biomarkerů s prognostickým a prediktivním potenciálem (IDH, 1p19q, MGMT, atd.) akcentující požadavek na dostupnost tkáně tumoru pro diagnostiku (Wirsching et Weller 2016). Molekulárně-biologické profilování nádoru tedy hraje čím dál větší roli, což odráží i nová revize WHO klasifikace nádorů CNS z roku 2016 (Louis et al., 2016). Chceme-li u značně heterogenních nádorů mozku a míchy uvažovat o efektivní cílené léčbě, neobejdeme se bez diagnostiky vyžadující odběr reprezentativní nádorové tkáně. Přes veškerý pokrok v léčbě onkologické tak zůstává operační výkon prvním a doposud nenahraditelným krokem při léčbě zhoubných nádorů nervového systému. Zásadní úloha neurochirurga pritom není jen umožnit tkáňovou diagnostiku, ale pozitivně ovlivnit další prognózu pacienta co největší nádorovou cytoredukcí při zachování dobré kvality života. Klinické studie opakovaně přinesly důkazy o významně lepším přežívání u pacientů po radiologicky definované "totální resekci“ (gross-total resection), než je tomu při resekci parciální (Brown et al., 2016).

Aktivní prístup k léčbě high-grade gliomů byl donedávna v kontrastu s nejistotou, jaký léčebný režim a kdy zvolit u pacientů s lowgrade gliomy. Mnoho pracovišt tak volilo iniciální strategii "watch and wait" a léčbu onkologickou zvažovali při záchytu změny charakteru nebo velikosti radiologického nálezu na MR. Přijmeme-li ovšem fakt, že gliální nádory počínaje gradem 2 představuji progresivní nádorové onemocnění, zvyšuje se při ponechání nádorové masy, tedy významně vyššího počtu populace nádorových buněk, pravděpodobnost dřivější progrese nejen velikosti (více dělících se buněk = rychlejší nárůst objemu nádoru), ale i stupně zhoubnosti (čím více buněk náchylných na genetické mutace vedoucí ke zvýšení stupně malignity, tím vyšší pravděpodobnost dřívější progrese biologického chování nádoru). Zásadní obrat $\checkmark$ léčbě pacientů s low-grade gliomy přinesla studie z roku 2012, která prokázala zlepšení celkového prežití těchto pacientů po časné resekci při srovnání s iniciální bioptickou verifikací a vyčkávání s chirurgickou léčbou na radiologickou progresi (Jakola et al., 2012).

Vzhledem k difuznímu charakteru většiny primárních nádorů CNS je role chirurgického řešení neslučitelně spjata s následnou léčbou onkologickou, která má získat kontrolu nad reziduálním nádorovým onemocněním za resekční hranicí. Ne jinak je tomu u sekundárních mozkových nádorů, tedy metastatického postižení mozku, kdy je účast onkologa nezastupitelná už z pohledu systémového charakteru onemocnění. Následující práce odborníků brněnského

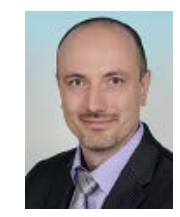

KORESPONDENČNÍ ADRESA AUTORA: doc. MUDr. Radim Jančálek, Ph.D., radim.jancalek@fnusa.cz Neurochirurgická klinika FN u sv. Anny v Brně a Lékařské fakulty Masarykovy univerzity

Pekařská 53, 65691 Brno

Cit. zkr: Neurol. praxi 2016; 17(5): 280-281 


\section{SLOVO ÚVODEM}

ASPEKTY SOUČASNÉNEUROONKOLOGIE

komplexního centra neuroonkologické péče prezentují současné možnosti diagnostiky a léčby primárních a sekundárních nádorů mozku.

\section{LITERATURA}

1. Brown TJ, Brennan MC, Li M, Church EW, Brandmeir NJ, Rakszawski KL, Patel AS, Rizk EB, Suki D, Sawaya R, Glantz M. Association of the extent of resection with survival in glioblastoma: a systematic review and meta-analysis. JAMA Oncol. 2016; 352(10): 987-996.

2. Jakola AS, Myrmel KS, Kloster R, Torp SH, Lindal S,
Narůstající prevalence nádorových onemocnění nervového systému bude do budoucna klást čím dál větší nároky na informovanost neurologické

Unsgård G, Solheim O. Comparison of a strategy favoring early surgical resection vs a strategy favoring watchful waiting in low-grade gliomas. JAMA. 2012; 308(18): 1881-1888.

3. Louis DN, Perry A, Reifenberger G, von Deimling A, Figarella-Branger D, Cavenee WK, Ohgaki H, Wiestler OD, odborné obce v problematice neuroonkologie a zaměření aktuálního čísla Neurologie pro praxi tak považuji za velmi prínosné a aktuální.

Kleihues P, Ellison DW. The 2016 World Health Organization Classification of Tumors of the Central Nervous System: a summary. Acta Neuropathol. 2016; 131(6): 803-820.

4. Wirsching H-G, Weller M. The Role of Molecular Diagnostics in the Management of Patients with Gliomas. Curr. Treat. Options Oncol. 2016; 17(10): 51 